\title{
Epidemiological Profile of Patients with Colorectal Cancer from a Hospital in Rio Grande do Sul, Brazil
}

\section{Perfil epidemiológico de pacientes com câncer colorretal de um Hospital no Rio Grande do Sul, Brasil}

\author{
Cecilia Albertoni Rohenkohl'1( Julia Pastorello ${ }^{2(1)}$ Natália Rodrigues Costa1(1) \\ Gilmara Pandolfo Zabot ${ }^{3 \odot}$ Ornella Sari Cassol ${ }^{4 \oplus}$
}

${ }^{1}$ Faculdade Meridional - IMED, Passo Fundo, RS, Brazil
2 Faculdade Meridional - IMED, Passo Fundo, RS, Brazil
${ }^{3}$ Pontificia Universidade Católica do Rio Grande do Sul, Canoas, RS, Brazil
${ }^{4}$ Faculdade Meridional - IMED, Passo Fundo, RS, Brazil

Address for correspondence Cecilia Albertoni Rohenkohl, Rua Tiradentes, 174, apartamento 401, Passo Fundo, RS, Brasil (e-mail: rohenkohlc@gmail.com).

J Coloproctol 2021;41(1):1-7.

\begin{abstract}
Keywords

- colorectal cancer

- primary prevention

- screening

- epidemiological profile

- socioeconomic factors

- public health
\end{abstract}

\section{Resumo}

received

June 23,2020

accepted

August 8, 2020
Objective The present study describes the epidemiological profile of patients with colorectal cancer (CRC) from the Hospital de Clínicas de Passo Fundo, Passo Fundo, RS, Brazil, between January 1, 2007 and December 31, 2016.

Method Retrospective analysis of secondary data of 1,001 patients from the Hospital Cancer Registry.

Results Most subjects were Caucasian males, with a mean age of 63.68 years old. The majority of patients had incomplete elementary education and were married. In addition, $44.5 \%$ of the patients had a family history of cancer. Most subjects with a positive past or current history of alcohol intake or smoking were male. The diagnosis was mostly based on anatomopathological findings, with a predominance of adenocarcinomas and upper rectum and distal colon localization. Most lesions were in advanced stages, and the liver was the most common site for metastasis. The predominant treatment was surgery with neoadjuvant/adjuvant therapy. After the first treatment, $49.0 \%$ of the patients reported complete remission. The survival rate was $78.8 \%$ in 10 months.

Conclusion The present research analyzed the profile of CRC patients.

Objetivo Descrever o perfil de pacientes com câncer colorretal (CCR) no Hospital de Clínicas de Passo Fundo, Passo Fundo, RS, Brasil, de 01 de janeiro de 2007 a 31 de dezembro de 2016.

Método Análise retrospectiva de dados secundários de 1.001 pacientes obtidos através do Registro Hospitalar de Câncer.
DOI https://doi.org/

$10.1055 / \mathrm{s}-0041-1725048$. ISSN 2237-9363.

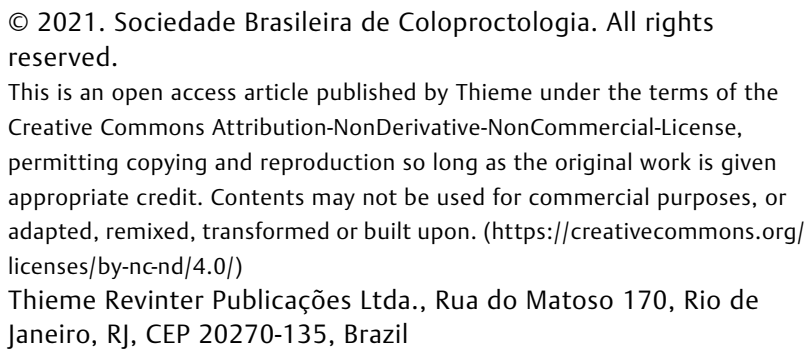

(C) 2021. Sociedade Brasileira de Coloproctologia. All rights reserved.

This is an open access article published by Thieme under the terms of the Creative Commons Attribution-NonDerivative-NonCommercial-License, permitting copying and reproduction so long as the original work is given appropriate credit. Contents may not be used for commercial purposes, or adapted, remixed, transformed or built upon. (https://creativecommons.org/ licenses/by-nc-nd/4.0/)

Thieme Revinter Publicações Ltda., Rua do Matoso 170, Rio de Janeiro, RJ, CEP 20270-135, Brazil 
Palavras-chave

- câncer colorretal

- prevenção primária

- rastreamento

- perfil epidemiológico

- fatores socioeconômicos

- saúde pública
Resultados Evidenciou-se predomínio do sexo masculino, com média de idade de 63,68 anos, majoritariamente caucasianos. O grau escolar prevalente foi fundamental incompleto e o estado civil foi casado. Um total de 44,5\% dos pacientes tinha histórico familiar de neoplasia. Em relação ao consumo de álcool/cigarro, dentre os que faziam ou já fizeram uso, a maioria era homem. O diagnóstico foi majoritariamente por meio anatomopatológico, com predomínio de adenocarcinoma e localização no reto superior e no cólon distal, ocorrendo mais comumente em estágios avançados, com a metástase hepática sendo a mais presente. O tratamento predominante foi cirurgia com adjuvância/neoadjuvância. Após o primeiro tratamento, 49,0\% dos pacientes apresentaram remissão completa. A sobrevida foi de 78,8\% em 10 meses.

Conclusão A presente pesquisa possibilitou a análise do perfil dos pacientes com CCR.

\section{Introduction}

Colorectal cancer (CRC) is a common neoplasm in oncology practice that affects thousands of people in Brazil each year. ${ }^{1,2}$ It is estimated that $>90 \%$ of colon and rectal tumors are adenocarcinomas. More rarely, these neoplasms are neuroendocrine, squamous, adenosquamous, spindle cells and undifferentiated carcinomas. ${ }^{3}$ These tumors consist in lesions arising from mucous cells from the colon and rectum. Although these neoplasms can be classified separately as colon or rectal cancer, they are usually identified as CRC due to their similarity. Colorectal cancer follows an adenomacarcinoma sequence, initially presenting as polyps, which are abnormal growths in the colon and rectum walls. ${ }^{4,5}$ It is believed that an adenomatous polyp takes an average time of 10 years to develop into a CRC. ${ }^{1}$

The risk factors related to the development of CRC can be classified as modifiable and nonmodifiable. Smoking, obesity, high alcohol and red meat intake, low fiber (fruits and vegetables) intake, and physical inactivity are modifiable risk factors. Nonmodifiable risk factors include age $>45$ years old, family history of CRC, some CRC-associated hereditary conditions, inflammatory bowel disease, type 2 diabetes mellitus, and history of pelvic and abdominal radiation therapy due to a previous cancer. In addition, recent studies point to calcium intake, aspirin use, and vitamin D supplementation as protective factors. ${ }^{6}$

According to the latest global cancer estimate, GLOBOCAN 2012, CRC accounted for 1.4 million new cases and for 700,000 deaths in 2012. Colorectal cancer is the third most diagnosed malignancy in men and the second in women (excluding nonmelanoma skin cancer), and it is the fourth leading cause of death among cancers as the most lethal gastrointestinal tumor. ${ }^{2}$

It was estimated that 36,360 new CRC cases would appear in Brazil from 2018 to 2019. Of these, 3,180 cases would occur in the state of Rio Grande do Sul, making it the third state with the highest of incidence CRC, after São Paulo and Rio de Janeiro. It was also assumed that 2,530 of these cases would occur outside the state capital, Porto Alegre, highlighting the need for an effective regional screening program over the next few years. ${ }^{2}$
A CRC epidemiological profile is extremely important because tumor screening allows for disease detection in asymptomatic patients and in a curable stage. In addition, colonoscopy screening may detect polyps that can be removed during the procedure, reducing the incidence of this type of cancer. ${ }^{7}$

As such, the present study aimed to describe the epidemiological profile of CRC and its conditioning and determining factors for people from the geographic region of Passo Fundo, RS, Brazil. Gender, age at diagnosis, ethnicity, educational level, marital status, family history of cancer, alcohol intake, and smoking habits were analyzed as variables to contribute to the clinical diagnosis of these patients, to favor better prognosis, to reduce unfavorable outcomes, and to determine any deficits that weaken public health policies. Additional variables included diagnosis method, histological type, disease staging, tumor topography, metastases location, therapeutic approach, follow-up findings, and survival rate.

\section{Methods}

This was an observational, cross-sectional, retrospective, descriptive study with secondary data obtained from the Cancer Registry of the Hospital de Clínicas de Passo Fundo, Passo Fundo, RS, Brazil (HCPF, in the Portuguese acronym), with no direct contact with the patient. These data referred to the period between January 1, 2007 and December 31, 2016.

The research included men and women $>18$ years old from any ethnical background diagnosed with CRC at the HCPF between January 1, 2007 and December 31, 2016. Colorectal cancer was identified according to the International Classification of Diseases for Oncology (ICD-O) as one of the following: C18.0 (cecum), C18.1 (appendix), C18.2 (ascending colon), C18.3 (hepatic flexure), C18.4 (transverse colon), C18.5 (splenic flexure), C18.6 (descending colon), C18.7 (sigmoid colon), C18.9 (colon, unspecified), C19.9 (rectosigmoid junction), and C20.9 (rectum), also grouped as right colon (cecum, appendix, ascending colon, hepatic flexure), transverse colon, left colon (splenic flexure and descending colon), sigmoid colon with rectosigmoid junction, and rectum. The rectum was divided in upper and middle/lower portions for treatment analysis because radiation therapy is applied only in middle/lower 
rectum neoplasms. Patients $<18$ years old and not belonging to the Cancer Registry were excluded from the sample.

The disease was staged according to the size, regional lymph nodes, and metastases (TNM) system. Clinical TNM was used in patients who did not had surgery, whereas pathological tumornode-metastasis (pTNM) was used in those who underwent surgery. This classification is based on three analyzes: size $(\mathrm{T})$, regional lymph nodes $(\mathrm{N})$, and metastases $(\mathrm{M})$. Patients with $\mathrm{T}_{1-2} \mathrm{~N}_{0} \mathrm{M}_{0}$ were classified as stage I, $\mathrm{T}_{3-4} \mathrm{~N}_{0} \mathrm{M}_{0}$ as stage II, $\mathrm{T}_{1-4} \mathrm{~N}_{1} \mathrm{M}_{0}$ as stage III, and patients with $\mathrm{M}_{\geq 1}$, regardless of $\mathrm{T}$ and $\mathrm{N}$ status, were classified as stage IV.

Statistical analysis was performed with the R software ( $R$ Foundation, Vienna, Austria) and the nnet package. At the descriptive analysis for sample characterization, the qualitative variables were shown as absolute frequency $(n)$ and relative frequency (\%), whereas the quantitative variables were shown as average, minimum, and maximum values. A multinomial logistic model was used for location and probability estimates.

The present study followed the rules set forth by resolution number 466 from 2012 with full compliance to the ethical terms. Data were collected after approval by the ethics and research committee (CEP, in the Portuguese acronym) from IMED under CAAE opinion number 17257519.6.0000.5319.

\section{Results}

From 2007 to 2016, 1,001 patients were diagnosed with CRC. The prevalence was slightly higher in male patients (53.5\%). The age of the patients ranged from 18 to 97 years old; most diagnoses occurred in the age group between 60 and 69 years old. The average age at diagnosis was 63.7 years old. Most patients were Caucasian $(92.5 \%$ ) (-Table 1 ).

Regarding educational status at diagnosis, most patients had incomplete elementary education; in fact, the educational level of most patients was lower than complete elementary school (53.3\%). Regarding marital status, most patients were married $(62.7 \%)$ (-Table 1 ).

The family history of any cancer was not informed in $44.5 \%$ of the records. Among the records with this information, $43.7 \%$ had a positive history of cancer. Regarding the use of substances related to a higher CRC incidence, that is, alcohol and tobacco, most patients denied drinking and/or smoking. Comparatively, smoking was more prevalent than alcohol intake (-Table 1 ). Most patients with a positive past or current history of alcohol intake and smoking were male, with rates of $91.4 \%$ and $70.8 \%$, respectively.

The diagnosis was based on an anatomopathological study of the lesion in $98.8 \%$ of the cases. The remaining patients were diagnosed based on metastasis biopsy and imaging tests. The most common histological type was adenocarcinoma (98.3\%); the remaining lesions included neuroendocrine tumor, small cell tumor, squamous cell tumor, melanoma, liposarcoma, gastrointestinal stromal tumor, non-Hodgkin lymphoma, and clinically malignant tumor.

The most common primary locations of the tumor were the upper rectum (24.8\%) and the sigmoid/rectosigmoid colon (24.7\%). Regarding disease stage at diagnosis, most
Table 1 Frequency distribution of characteristics from the population diagnosed with colorectal cancer at the Hospital das Clínicas de Passo Fundo, Passo Fundo, RS, Brazil, between 2007 and 2016

\begin{tabular}{|c|c|c|}
\hline Variables & $\begin{array}{l}\text { Number of } \\
\text { subjects }\end{array}$ & $\%$ \\
\hline \multicolumn{3}{|l|}{ Gender } \\
\hline Male & 536 & 53.5 \\
\hline Female & 465 & 46.5 \\
\hline \multicolumn{3}{|l|}{ Age (years old) } \\
\hline$\leq 49$ & 147 & 14.7 \\
\hline $50-59$ & 214 & 21.4 \\
\hline $60-69$ & 276 & 27.6 \\
\hline $70-79$ & 242 & 24.2 \\
\hline$\geq 80$ & 122 & 12.2 \\
\hline \multicolumn{3}{|l|}{ Ethnicity } \\
\hline Caucasian & 926 & 92.5 \\
\hline Mixed & 34 & 3.4 \\
\hline African descent & 16 & 1.6 \\
\hline Not informed & 25 & 2.5 \\
\hline \multicolumn{3}{|l|}{ Educational status } \\
\hline Illiterate & 41 & 4.1 \\
\hline $\begin{array}{l}\text { Incomplete elementary } \\
\text { education }\end{array}$ & 492 & 49.2 \\
\hline $\begin{array}{l}\text { Complete elementary } \\
\text { education }\end{array}$ & 113 & 11.3 \\
\hline Complete high school education & 119 & 11.9 \\
\hline Incomplete college education & 13 & 1.3 \\
\hline Complete college education & 82 & 8.2 \\
\hline Not informed & 141 & 14.1 \\
\hline \multicolumn{3}{|l|}{ Marital status } \\
\hline Single & 131 & 13.1 \\
\hline Married & 628 & 62.7 \\
\hline Widower/widow & 171 & 17.1 \\
\hline Legally separated & 46 & 4.6 \\
\hline Common-law marriage & 15 & 1.5 \\
\hline Not informed & 10 & 1.0 \\
\hline \multicolumn{3}{|l|}{ Family history of cancer } \\
\hline Yes & 243 & 24.3 \\
\hline No & 313 & 31.3 \\
\hline Not informed & 445 & 44.5 \\
\hline \multicolumn{3}{|l|}{ Alcohol use history } \\
\hline Never used alcohol & 565 & 56.4 \\
\hline Past alcohol use & 61 & 6.1 \\
\hline Yes & 55 & 5.5 \\
\hline Not informed & 320 & 32.0 \\
\hline \multicolumn{3}{|l|}{ Smoking history } \\
\hline Never smoked & 399 & 39.9 \\
\hline Former smoker & 151 & 15.1 \\
\hline Yes & 161 & 16.1 \\
\hline Not informed & 290 & 29.0 \\
\hline
\end{tabular}




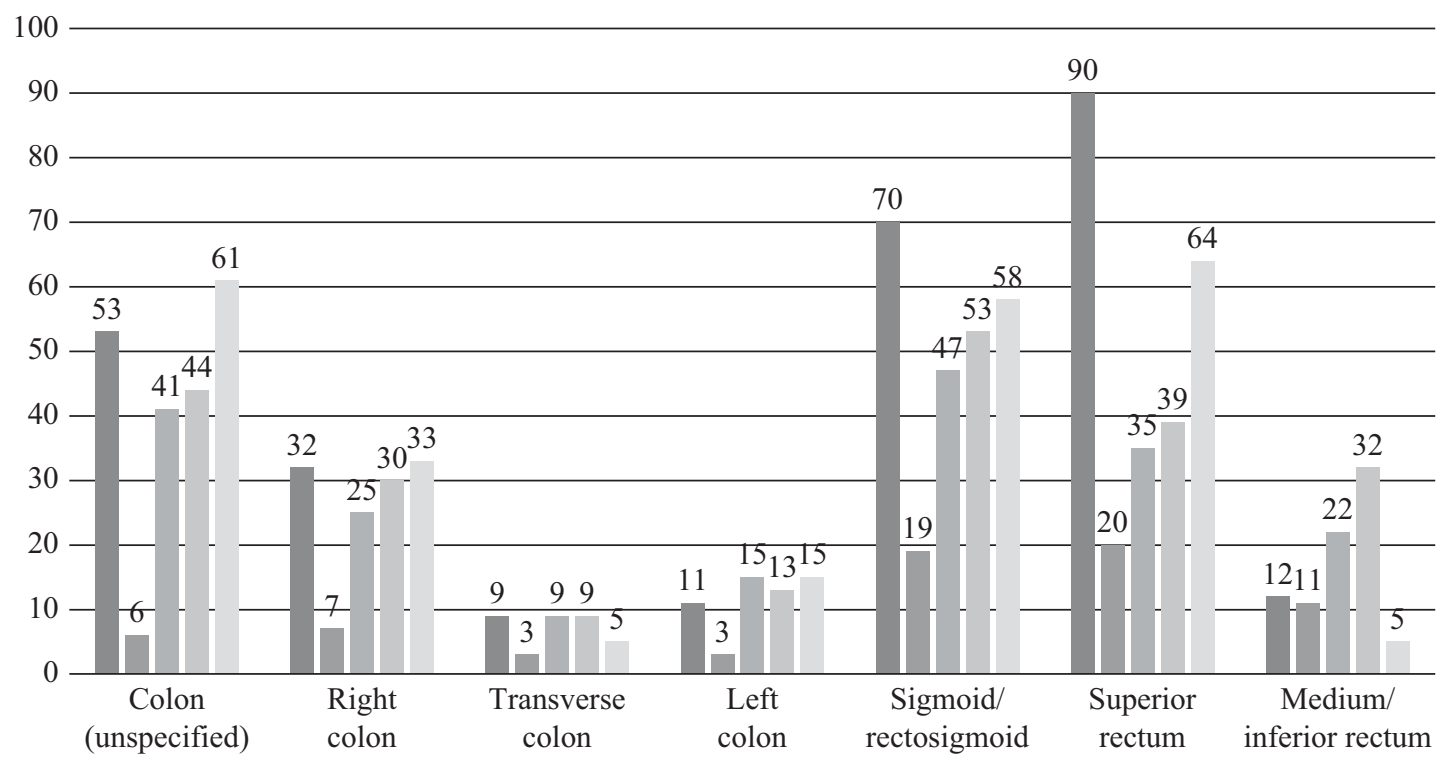

$\square$ Not informed $\square$ Stage I $\square$ Stage II $\square$ Stage III $\square$ Stage IV

Fig. 1 Location-based staging in absolute numbers.

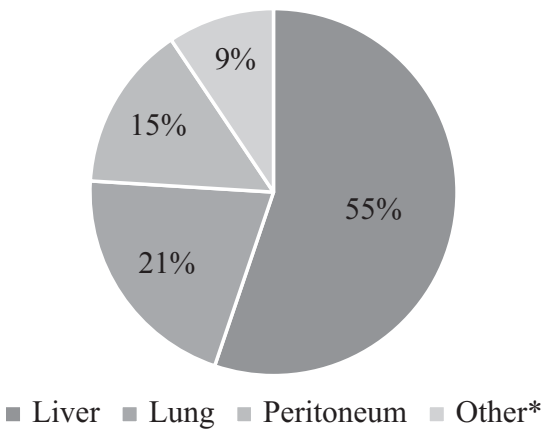

Fig. 2 Metastases (in percentage). ${ }^{*}$ Other: skull and face bones, head and neck, ovaries, lymph nodes, brain, bile ducts, pancreas, heart, endocervix, epididymis, and not informed.

cases were advanced, regardless of tumor location, with a higher prevalence of stage-III lesions (- Figure $\mathbf{1}$ ).

Among the 243 patients with stage-IV CRC, 74.1\% had metastasis in a single site, $21.0 \%$ had 2 metastatic sites, and $3.3 \%$ had $\geq 3$ metastatic sites; this information was not available for $1.7 \%$ of the cases. The most common metastasis sites were the liver (55\%) and the lungs (21\%) (- Figure 2).

Considering the 805 patients who were treated, 628 underwent surgery. Among them, 94 and 288 patients were submitted to neoadjuvant and adjuvant therapy, respectively. The predominant adjuvant therapy was chemotherapy. Among the 177 patients who were not submitted to surgery but were treated, all had stage-IV CRC, and the majority $(n=168)$ underwent chemotherapy alone (-Figure $\mathbf{3}$ ).

The remaining 196 subjects were not treated. Among these subjects, 3 refused therapy, 9 were treated at another hospital other than the HCPF, 10 presented advanced disease or were critically ill, 12 died before treatment, and 162 patients did not receive treatment due to unspecified reasons.
At the end of treatment, $49.0 \%$ of the patients had complete remission, and $16.0 \%$ had partial remission of the disease. In addition, the disease was stable in $9.7 \%$ and progressing in $7.8 \%$ of the patients; $11.9 \%$ of the patients died. Posttreatment information was missing in $6.6 \%$ of the medical records. Up to the end of data collection from the Cancer Registry, which lasted for $\sim 10$ months, 789 patients had survived. Among those who did not survive, 165 subjects died as a direct result of the disease, and 47 had other causes or an unknown cause of death.

Regarding probabilities, the chance of right colon cancer is, on average, $9.3 \%$ higher in women, whereas the chance of upper rectum tumor is, on average, $4.12 \%$ higher in men. Regarding alcohol intake, the chance of left colon cancer is, on average, $2.47 \%$ higher in patients with a past or current history of alcohol intake than in subjects with a negative history. The chance of sigmoid/rectosigmoid colon cancer is, on average, $2.19 \%$ higher in smokers and former smokers compared with nonsmokers (-Table 2).

\section{Discussion}

Most Brazilian studies indicate a slightly higher CRC prevalence in males, ranging from 51.3 to $60 \%{ }^{8-12}$ This is consistent with our study, in which $53.5 \%$ of the patients were males. Some authors believe that this occurs because women seek more specialized health services and participate more in prevention programs when compared with men. ${ }^{11}$ This finding may also be explained by the higher exposure of males to risk factors, as observed in our study, in which $91.4 \%$ of the subjects with a past or current history of alcohol intake, and $70.8 \%$ of the smokers/former smokers were men.

Most diagnoses occurred in subjects aged between 50 and 79 years old (73.2\%), which is consistent with other reports. ${ }^{11,13}$ However, the literature shows an increase in the 


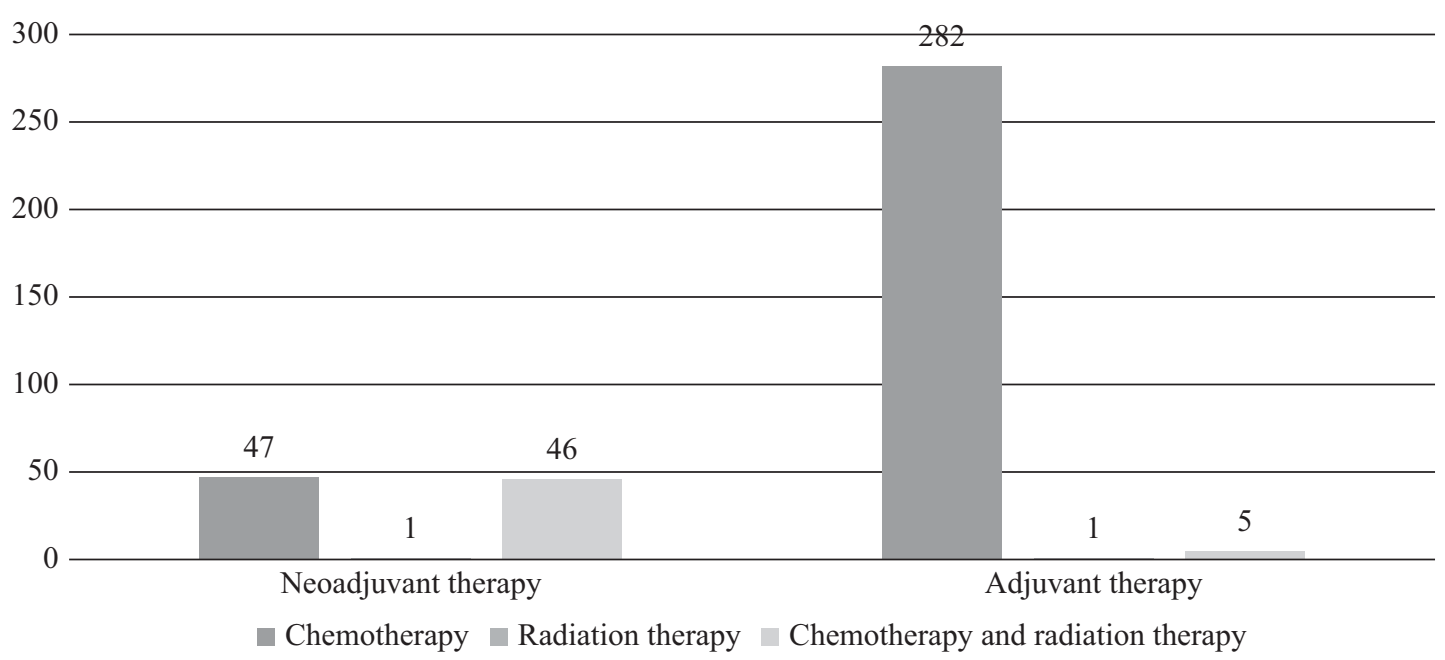

Fig. 3 Neoadjuvant and adjuvant therapies in absolute numbers.

Table 2 Probable location

\begin{tabular}{|l|l|l|l|l|l|l|}
\hline \multirow{2}{*}{ Location } & \multicolumn{2}{l|}{ Gender } & \multicolumn{2}{l|}{ Alcohol use } & \multicolumn{2}{l|}{ Smoking } \\
\cline { 2 - 7 } & Female & Male & Yes & Never & Yes & Never \\
\hline Right colon & $20.98 \%$ & $11.65 \%$ & $12.94 \%$ & $16.33 \%$ & $15.45 \%$ & $15.82 \%$ \\
\hline Transverse colon & $3.81 \%$ & $4.90 \%$ & $3.53 \%$ & $4.92 \%$ & $4.47 \%$ & $5.38 \%$ \\
\hline Left colon & $5.99 \%$ & $8.16 \%$ & $9.41 \%$ & $6.94 \%$ & $6.91 \%$ & $8.23 \%$ \\
\hline Sigmoid/ rectosigmoid colon & $29.97 \%$ & $31.93 \%$ & $31.77 \%$ & $29.53 \%$ & $31.30 \%$ & $29.11 \%$ \\
\hline Superior rectum & $39.24 \%$ & $43.36 \%$ & $42.35 \%$ & $42.28 \%$ & $41.87 \%$ & $41.46 \%$ \\
\hline
\end{tabular}

early diagnosis of CRC, as observed by Saad-Hossne et al., ${ }^{9}$ who reported most diagnoses in subjects aged between 40 and 50 years old. This trend is now observed in the United States, ${ }^{14}$ where authors predict an increase in CRC incidence of almost $30 \%$ in patients aged between 35 to 49 years old by 2030 . The American Cancer Society ${ }^{4}$ recommends that screening in patients at regular risk, that is, with no personal or family history of CRC or some types of polyps, no history of inflammatory bowel disease or CRC-related hereditary syndromes, and who have never received pelvic irradiation, must start at 45 years old. The average age of our patients was 63.7 years old, which is consistent with other studies..$^{8-13,15,16}$

In our study, virtually all subjects were Caucasian (92.5\%), which is not observed in other studies evaluating ethnicity. In a study carried out in Sergipe, in the Northeast of Brazil, ${ }^{16}$ this information was missing from $43.66 \%$ of the medical records; among the remaining subjects, $53.55 \%$ were Caucasian, $45.16 \%$ had mixed ethnicity, and $1.29 \%$ were of African descent. A study from the United States ${ }^{17}$ showed that the incidence of CRC in African Americans is $20 \%$ higher when compared with Caucasians. These findings may be justified by the fact that a significant number of medical records from the Sergipe study was missing and that there is a higher proportion of Caucasians $(81.5 \%)$ in the population of Rio Grande do Sul. ${ }^{18}$

The educational level from our sample was consistent with the findings from Carvalho, ${ }^{12}$ who reported that most subjects were illiterate or had an incomplete elementary education. Reduced access to education is associated with other types of cancer, such as oral, pharynx, esophagus, liver, gastric, colorectal, and cervical neoplasms. ${ }^{19-21}$ The low educational level is associated with a scarcity of knowledge regarding risk and protection factors, symptoms, screening and prevention policies, and lower adhesion to oncologic treatment. ${ }^{12}$ Along with other factors, such as low income per capita, aging and marital status, the low educational status increases the prevalence of failures in cancer prevention and screening, resulting in later diagnoses. ${ }^{11}$

A family history of cancer was positive in $43.7 \%$ of the subjects with available information, in contrast with other reports, in which the rates ranged from 11.0 to $11.3 \% .^{8,9}$ Such discrepancy occurs because other studies evaluate the family history of CRC, whereas we analyzed data from the database of the hospital, which reports a positive family history for any type of cancer.

Most subjects denied alcohol intake. Among those with a positive past or current history of alcohol intake, most patients were males, consistent with Carvalho et al. ${ }^{11} \mathrm{~A}$ similar rate was reported by the Instituto Nacional do Câncer (INCA, in the Portuguese acronym), ${ }^{22}$ with 48.9 to $72.1 \%$ of men declaring a positive past or current history of alcohol intake. Excluding medical records with no available relevant information, $43.9 \%$ of the patients were smokers or former smokers, which is consistent with other studies that show a 
prevalence of 43.6 to $46 \%{ }^{9,11}$ Most of these subjects were men, which is consistent with the literature. ${ }^{11,23}$

The most predominant histological type in our study was adenocarcinoma (98.3\%), which is consistent with the literature. $2,5,7,10,11$ The most common location was the superior rectum, closely followed by the sigmoid/rectosigmoid colon. This data is also consistent with other articles, in which these two regions appear as the most affected locations; other authors, however, report the sigmoid/rectosigmoid colon $^{8,10,15}$ or the rectum ${ }^{9,16}$ as the most prevalent CRC site.

In our sample, most colorectal neoplasms were diagnosed in advanced stages, which is in line with literature reports. $^{8-10,12,13,15,16}$ In addition, the majority of cases were in stage III, which is consistent with other studies. ${ }^{9,12,13,15,16}$ This shows that CRC diagnosis is late, occurring in stages when its resection is more complex or even impossible, reducing the chances of cure. Late diagnoses result from the lack of effective public policies, including the unavailability of an infrastructure for tracking medium- or high-risk subjects and the lack of population awareness through media channels, such as what occurs regarding breast cancer screening. ${ }^{8}$ Regarding metastases, the most affected organ was the liver, as reported by Valadão et al. $^{8}$

According to the American Cancer Society, ${ }^{4}$ the therapeutic regimen depends on tumor stage and individual features of the patient. For stages I and II, the standard treatment is surgical, but it can be complemented by neoadjuvant therapy for tumor control or reduction, or by adjuvant therapy in cases of incomplete dissection or to improve outcomes. ${ }^{4,15}$ For stage III, surgery, when feasible, is often associated with other treatments, such as chemotherapy and radiation therapy. ${ }^{4,15}$ For stage IV, that is, metastatic CRC, surgery is only used as a palliative treatment, since the main therapeutic modality is chemotherapy alone or combined with radiation therapy. ${ }^{4}$ Since most patients in the present study were in advanced stages, surgery combined with neoadjuvant or adjuvant therapy is the recommended approach.

The survival rate in our sample was of $78.8 \%$, which is consistent with Fey et al., ${ }^{15}$ who reported a 10-month survival, a time period similar to the data collection at the Cancer Registry. In contrast, Carvalho ${ }^{12}$ found a survival rate of $\sim 50 \%$, but this discrepancy can be justified by the fact that this last study analyzed a 5-year survival rate.

The main limitation of the present study was related to its retrospective nature and to the incomplete information in some medical records, which partially results from the fact that the Cancer Registry includes all patients diagnosed at the HCPF, but some of them are treated in other hospitals or cities. Despite this, the establishment of a clinical and epidemiological profile was feasible, and most variables were consistent with what was expected by the researchers.

\section{Conclusion}

The present research aimed to describe the profile of the population with CRC treated at the HCPF between 2007 and 2016. The following variables were analyzed: gender, age at diagnosis, ethnicity, educational level, marital status, family history of cancer, personal history of alcohol intake and smoking habits, diagnostic method, histological type, tumor location, TNM staging, metastasis, treatment, posttreatment disease status, and survival.

The sociodemographic profile of our patients revealed that most subjects were Caucasian males, aged between 60 and 69 years old, married, and with a low educational level. Most patients had no family history of cancer, denied alcohol intake and were nonsmokers.

Virtually all diagnoses were based on biopsy findings, and the most common histological type was adenocarcinoma. The most common tumor location was the distal colon. Most patients were diagnosed with the disease in advanced stages, and the most common site for metastasis was the liver. These findings highlight the need for more effective public policies, including investments in primary CRC prevention and greater use of mass media to disseminate information about this condition. These measures will increase the early diagnosis of CRC, the survival of patients and, most importantly, their quality of life.

The most common treatment was surgery combined with adjuvant therapy. This finding is consistent with the population analyzed, since most patients presented advanced CRC. Approximately half of the study population showed complete CRC remission after treatment. The survival rate in $\sim 10$ months was of $78.8 \%$.

\section{Conflict of Interests}

The authors have no conflict of interests to declare.

\section{References}

1 Haraldsdóttir S, Einarsdóttir HM, Smáradóttir A, Gunnlaugsson A, \& Hálfdanarson pR Krabbamein í ristli og endaparmi. Icelandic Med. Assoc. 2014:75-83

2 INCA. Estimativa 2018. Instituto Nacional de Câncer José Alencar Gomes da Silva. 2017. Doi: 978-85-7318-283-5

3 Fleming M, Ravula S, Tatishchev SF, Wang HL. Colorectal carcinoma: Pathologic aspects. J Gastrointest Oncol 2012;3(03): 153-173

4 American Cancer Society. American Cancer Society ARRUMAR ESSE. Am. Cancer Soc. Guidel. Color. Cancer Screen. 1 (2019

5 Milagros L, Cardoza S, Sibim AC, \& Gamarra CJ. Tendência da Mortalidade por Câncer Colorretal no Estado do Paraná e no Município de Foz do Iguaçu, 1980 a 2013 Trends in Colorectal Cancer Mortality in the State of Parana and the City of. >63, 87-93 2017

6 Wolf AM. D, et al. Colorectal Cancer Screening for Average-Risk Adults : 2018 Guideline Update From the American Cancer Society. in 250-2812018. Doi: 10.3322/caac.21457

7 Inadomi JM. Screening for Colorectal Neoplasia. N Engl J Med 2017;376(02):149-156. Doi: 10.1056/NEJMcp1512286

8 Valadão M, Leal RA, Barbosa LC, Carneiro M, Muharre RJ. Perfil dos pacientes portadores de câncer colorretal operados em um hospital geral: Necessitamos de um programa de rastreamento acessível e efetivo. Rev Bras Coloproctol 2010;30:160-166

9 Saad-Hossne R, et al. Estudo Retrospectivo de Pacientes Portadores de Câncer Colorretal Atendidos na Faculdade de Medicina de Botucatu no período de 2000-2003. Rev Bras Coloproctol 2005;25:31-37

10 da Natividade LF, et al. Análise Do Perfil Epidemiológico, Clínico E Patológico De Pacientes Com Colectomia Por Câncer Colorretal Em Ponta Grossa, Paraná. J Coloproctol (Rio J) 2017; $37: 100$ 
11 Carvalho GD, Araújo RD. DAmorim de JM. G. C, Sousa WM, \& Silva MB. MEpidemiologia dos Pacientes Portadores de Câncer Colorretal em um Centro de Saúde em Teresina - PI. An. da Most. Pesqui. em Ciência e Tecnol. 20172018

12 Carvalho RA. de O. de. Análise do perfil epidemiológico e sobrevida de pacientes com câncer colorretal em um hospital universitário de 2000 a 2010. Bibl. Digit. da USP; 2014

13 Girardon DT, De Moraes AB, Jacobi LF. Epidemiologia de Pacientes com Câncer Colorretal Submetidos à Tratamento Cirúrgico em Hospital de Referência Público no Período de 5 anos. Repositório Digit. da UFSM; 2016

14 Deen KI, Silva H, Deen R, Chandrasinghe PC. Colorectal cancer in the young, many questions, few answers. World J Gastrointest Oncol 2016;8(06):481-488

15 Fey A, et al. Perfil epidemiológico e evolução dos pacientes com câncer do colon e reto atendidos no Hospital Regional Alto Vale no ano de 2008. Arq. Catarinenses Med. 2010;39:62-67

16 Torres Neto Jda R, et al. Estudo Demográfico do Câncer de Cólon e Reto no Estado de Sergipe. Rev Bras Coloproctol 2008;28:215-222

17 Augustus GJ, Ellis NA. Colorectal Cancer Disparity in African Americans: Risk Factors and Carcinogenic Mechanisms. Am J Pathol 2018;188(02):291-303
18 Silva da WM. Novembro negro na Ufrgs: o papel da comunicação no incentivo à (re)construção do imaginário social dos estudantes negros. Intercom - Rev. Bras. Ciências da Comun 2018;31;

19 Alicandro G, Frova L, Sebastiani G, El Sayed I, Boffetta P, La Vecchia C. Educational inequality in cancer mortality: a record linkage study of over 35 million Italians. Cancer Causes Control 2017;28 (09):997-1006

20 Magalhães LP, Oshima CT, Souza LG, Lima JM, Carvalho Ld, Forones NM. [Weight, educational achievement, basic sanitation, alcoholism, smoking and eating habit in patients with gastric cancer]. Arq Gastroenterol 2008;45(02):111-116

21 de Vries E, Arroyave I, Pardo C, et al. Trends in inequalities in premature cancer mortality by educational level in Colombia, 1998-2007. J Epidemiol Community Health 2015; 69(05):408-415

22 Ministério da Saúde \& Instituto Nacional do Câncer. Falando sobre Câncer do Intestino: Orientações Úteis ao Usuário, Fatores de Risco e Proteção. 2003

23 Petroianu A, Alberti LR, de Lima DC, Hauter HL, Rodrigues KC, Mendes JC. Achados colonoscópicos em pessoas sem quadro clínico de doença colorretal. Arq Gastroenterol 2009;46(03): 173-178 